\title{
Pengaruh Pembiayaan terhadap PDRB Sektor Perdagangan, Hotel, dan Restoran Ditinjau dari Pariwisata Syariah Provinsi Aceh
}

\author{
The effect of financing on the GRDP of trade, hotel, and restaurant sectors terms of Islamic \\ tourism in Aceh province
}

\section{Vina Febyningtyas}

Program Studi D4 Keuangan Syariah, Politeknik Negeri Bandung

E-mail: vinafeiyas@gmail.com

\section{Endang Hatma Juniwati}

Jurusan Akuntansi, Politeknik Negeri Bandung

E-mail: endang.hatma@polban.ac.id

\section{Setiawan}

Jurusan Akuntansi, Politeknik Negeri Bandung

E-mail: setiawan@polban.ac.id

\begin{abstract}
Aceh Province is one of the provinces in Indonesia that implements and implements Islamic Law. Qanun is a statutory regulation applied in Aceh for the development of governance and community life in Aceh Province. This study aims to see whether there are a relationship and influence between BUS and UUS on the Gross Regional Domestic Product of the Trade, Hotel, and Restaurant sector. This study uses secondary data. The sample in this study was determined using probability sampling. This research method is an associative descriptive method with a quantitative approach. The analytical tool used in this study is a simple regression analysis with the help of applications. The results of the study are that there are a strong relationship and contribution as well as a positive influence between BUS and UUS Financing and the Gross Regional Domestic Product of Trade, Hotel, and Restaurant Sector of Aceh Province Period 2010-2018.
\end{abstract}

Keywords: financing, Islamic tourism, GRDP.

\section{Pendahuluan}

\subsection{Latar Belakang}

Wisata halal telah lama menjadi model yang diandalkan oleh banyak negara mayoritas Muslim (Djakfar Muhammad, 2017). Negara yang mulai meningkatkan pariwisata halal yaitu Jepang. Pemerintah Jepang yang berupaya untuk memfasilitasi para wisatawan muslim sehingga merasa aman dan nyaman ketika berwisata. Keberhasilan Jepang dapat dilihat dengan diraihnya penghargaan pada World Halal Tourism Award sebagai "World Best Non OIC (Organization of Islamic Conference) Emerging Halal Destination" pada tahun 2016 (Halal Media Japan, 2016) Meningkatanya wisatawan muslim di Jepang, menjadikan permintaan produk dan fasilitas halal meningkat di negara tersebut. Sehingga terbentuklah Japan Halal Association (JHA) yang mengawasi dan memberikan sertifikasi halal dan mengkampanyekan tentang penyediaan tempat untuk shalat (Japan Halal Association, 2012). Selain itu, mendorong beberapa perusahaan tur jepang untuk meluncurkan paket tur halal bagi wisatawan muslim yang berbasis di Tokyo dan Osaka (Yusof \& Shutto, 2014). Selain itu, negara lainnya adalah Turki yang menjadikan sejarah peradaban 
Islam dan kekhasan makanan halal sebagai instrumen untuk menarik dunia Muslim untuk mengunjungi Turki (Amnar et al., 2017). Hal tersebut berdampak pada pertumbuhan ekonomi Turki yang pariwisatanya menyumbang pendapatan besar. Ini disebabkan karena banyak komunitas muslim yang ingin ke Turki untuk menikmati nuansa Islami yang ditawarkan (Aliah, 2016).

Begitupun Indonesia dengan kepulauan terbesar di dunia memiliki beragam kekayaan alam. Pariwisata syariah unggulan yang berada di Indonesia yaitu Provinsi NTB yang telah memiliki perda tentang pariwisata syariah dan sertifikasi halal. Namun disisi lain, menurut penulis Aceh belum menjadi destinasi wisata yang mampu menyedot pengunjung domestik maupun mancanegara untuk datang secara khusus dengan tujuan berwisata. Ini menunjukkan bahwa Provinsi Aceh perlu adanya pengembangan sektor pariwisata yang memainkan peranan penting dalam ekonomi dunia karena dianggap sebagai salah satu kontributor pertumbuhan lapangan kerja dan pertumbuhan ekonomidi negara manapun. Di sisi lain, sektor pariwisata dalam situasi saat ini menempati posisi ke-8 dalam kontribusinya terhadap Pendapatan Asli Daerah Aceh (Fahreza \& Masbar, 2018).

Aceh merupakan salah satu provinsi di Indonesia yang menjalankan dan menerapkan syariat Islam. Pemerintah Daerah setempat memiliki qanun yaitu sejenis dengan peraturan daerah syariah yang menjadi acuan penyelenggaraan pemerintahan dan kehidupan masyarakat Aceh. Termasuk dalam bidang ekonomi, masyarakat disana memiliki motivasi yang sangat besar untuk menjalankan perekonomian sesuai dengan syariat Islam. Qanun yang mendukung penerapan ekonomi syariah di antaranya adalah Nomor 8 Tahun 2016 tentang sistem jaminan produk halal untuk melindungi masyarakat dari konsumsi barang haram. Faktanya Aceh memenangkan tiga kategori pada Kompetisi Pariwisata Halal Nasional 2016 versi Kementerian Pariwisata Republik Indonesia. Adapun kategori tersebut yaitu Destinasi Budaya Ramah Wisatawan Muslim Terbaik, Airport Ramah Wisatawan Muslim Terbaik (Bandara Sultan Iskandar Muda) dan Daya Tarik Wisata Terbaik (Masjid Raya Baiturrahman Banda Aceh) . Beberapa diantara peneliti jarang untuk meneliti adanya pariwisata sebagai alternatif untuk meningkatkan pendapatan domestik regional bruto. Padahal jika kita lihat dari segi daya tarik wisatawan banyak yang tertarik untuk mengunjungi Aceh melihat berbagai panorama keindahan. Berikut merupakan tabel kunjungan wisatawan Provinsi Aceh Tahun 2014-2018:

Tabel 1. Kunjungan Wisatawan Provinsi Aceh Tahun 2010-2018

\begin{tabular}{|c|c|c|c|c|c|}
\hline Wisatawan & $\mathbf{2 0 1 4}$ & $\mathbf{2 0 1 5}$ & $\mathbf{2 0 1 6}$ & $\mathbf{2 0 1 7}$ & $\mathbf{2 0 1 8}$ \\
\hline Domestik & 1.377 .541 & 1.662 .528 & 2.077 .797 & 2.288 .625 & 2.391 .968 \\
\hline Mancanegara & 50.721 & 54.588 & 76.452 & 75.758 & 106.281 \\
\hline Total & 1.428 .262 & 1.717 .116 & 2.154 .249 & 2.364 .383 & 2.498 .249 \\
\hline
\end{tabular}

Sumber: Disbudpar Aceh (data diolah kembali)

Berdasarkan Tabel 1, tingkat wisatawan tahun 2014 - 2018 terdapat kenaikan secara terus menerus dari setiap tahunnya. Kenaikan yang terjadi pada tahun 2015 dibandingkan dengan tahun 2014 sebesar 20,2\%. Sedangkan pada tahun 2016 sangat meningkat dibandingkan dengan tahun 2015 sebesar 25,5\%. Berbeda dengan tahun sebelumnya, kenaikan pada tahun 2017 tidak terlalu besar yaitu 9,8\%, dan pada tahun 2018 mengalami kenaikan sebesar 5,7\%. Rata - rata pertumbuhan yang terjadi selama 5 tahun yaitu 15,3\%. Hal ini menjadi suatu peluang bagi warga lokal untuk meningkatkan suatu bisnis atau industri, khususnya dalam kegiatan usaha perdagangan, hotel dan restoran. Ini sangat diperlukan dalam dunia pariwisata untuk meningkatkan pendapatan daerah.

Pembiayaan merupakan aktivitas utama bank dalam menyalurkan dananya dan untuk mendapatkan keuntungan bagi bank. Oleh karena itu BUS dan UUS harus lebih berhati-hati untuk mengalokasikan dana pembiayaannya (Apriyanthi et al., 2019). Lembaga keuangan syariah berperan sebagai pihak yang memberikan fasilitas pembiayaan kepada masyarakat yang berminat untuk 
melakukan usaha dalam bidang jasa serta perdagangan, hotel dan restoran. Pembiayaan bank syariah memberikan peran positif untuk output dan penyerapan pertumbuhan tenaga kerja, meskipun dengan peran yang tidak terlalu besar (Setiawan, 2019). Diantaranya Bank Umum Syariah dan Usaha Unit Syariah yang memberikan pembiayaan kepada masyarakat untuk bisa mengembangkan kegiatan lapangan usaha mereka dalam bidang pariwisata.

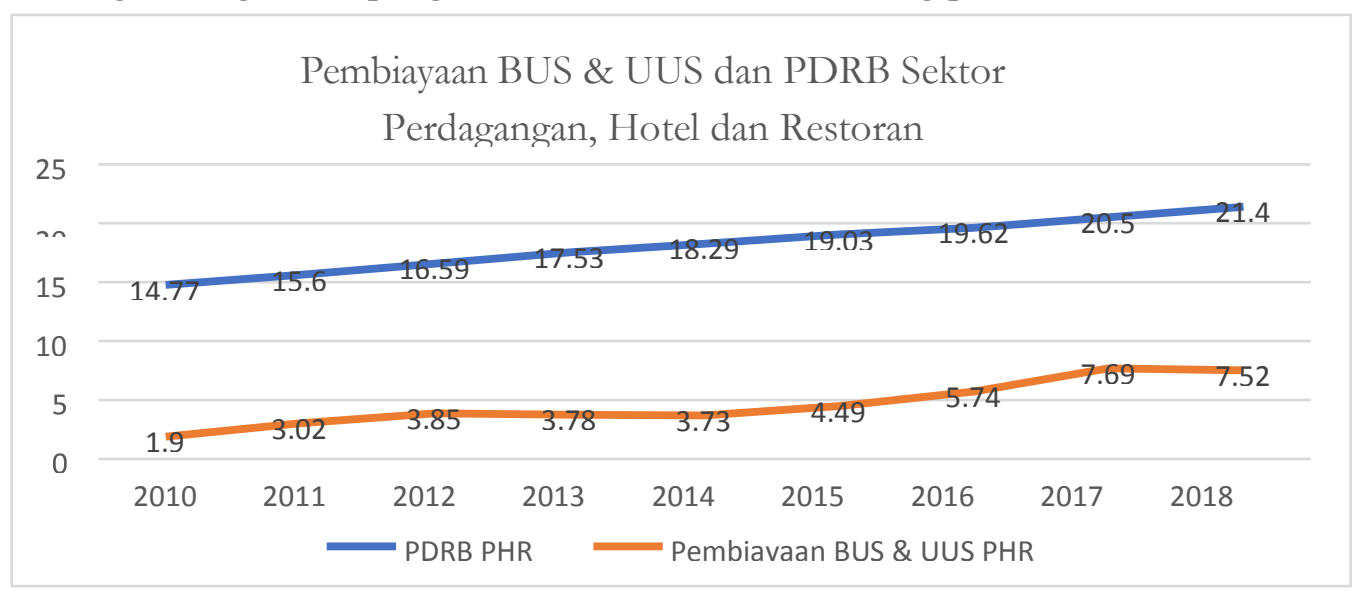

Gambar 1. Pembiayaan BUS \& UUS dan PDRB Sektor Perdagangan, Hotel, dan Restoran Sumber : (SPS OJK 2010-2018, 2019) dan (BPS ACEH, 2019) (data diolab kembali)

Berdasarkan grafik pada Gambar 1.1, keseluruhan pembiayaan BUS dan UUS serta PDRB sektor Perdagangan, Hotel dan Restoran mengalami kenaikan dari tahun 2010 - 2018. Pembiayaan yang mengalami penurunan pada tahun 2013 dan 2014. Namun penurunan tersebut tidak terlalu signifikan. Tahun 2013 persentase penurunan pertumbuhan senilai 1,8\% dan tahun 2015 mengalami persentase kenaikan sebesar 2,7\%. Kenaikan kembali terjadi ditahun 2017 persentasenya senilai 3,3\%. Ditinjau dari tahun ke tahun, pemberian pembiayaan mengalami kenaikan yang cukup signifikan walaupun di periode tahun tertentu terdapat penurunan. Dilihat dari penyaluran pembiayaan untuk sektor perdagangan hotel dan restoran yang naik turun maka penulis menemukan adanya permasalahan pada pembiayaan sector perdagangan, hotel dan restoran Provinsi Aceh.

Menurut penelitian (Suryadi et al., 2014) yang berjudul Analisis Pembiayaan Sektor Perdagangan, Hotel, dan Restoran pada Perbankan Syariah di Indonesia dengan hasil variabel IPI, SBK, dan ERP signifikan positif oleh rasio pembiayaan sektor perdagangan, hotel, dan restoran. Sedangkan, DPK, NPF, Bonus SBIS, INF signifikan negatif oleh oleh rasio pembiayaan sektor perdagangan, hotel dan restoran. Penelitian selanjutnya oleh (Saleh \& Anisah, 2018) dengan judul Pariwisata Halal di Aceh : Gagasan dan Realitas mendapatkan hasil bahwa Kesuksesan implementasi wisata halal di Aceh yang membahas perspektif komunikasi pemasaran dan kreativitas pesan dari sisi kehumasan. Selanjutnya peneliti (El-Gohary, 2016) dengan judul Halal Tourism, is it really halal? memberikan hasil bahwa besarnya pariwisata halal dunia dipengaruhi oleh kebutuhan wisatawan untuk mengembangkan hotel dan organisasi pariwisata halal dengan mengemukakan strategi dan produk organisasi pariwisata hala tersebut untuk meningkatkan kinerjanya.

Berkaitan dengan latar belakang masalah mengenai pariwisata syariah dengan peranan bank sebagai penyaluran pembiayaan, maka penulis tertarik untuk melakukan penelitian tentang "Pengaruh Pembiayaan BUS dan UUS Terhadap Produk Domestik Regional Bruto Sektor Perdagangan, Hotel dan Restoran Ditinjau dari Pariwisata Syariah Provinsi Aceh“.

\subsection{Rumusan Masalah}

1. Apakah ada hubungan dan kontribusi yang menyebabkan besarnya pembiayaan BUS dan UUS terhadap Produk Domestik Regional (PDRB) sektor perdagangan hotel dan restoran 
Provinsi Aceh Periode 2010-2018?

2. Apakah ada pengaruh yang menyebabkan besarnya pembiayaan BUS dan UUS terhadap Produk Domestik Regional (PDRB) sektor perdagangan hotel dan restoran Provinsi Aceh Periode 2010-2018?

\section{Kajian Pustaka}

\subsection{Produk Domestik Regional Bruto Harga Konstan}

PDRB atas dasar harga konstan menunjukkan nilai tambah barang dan jasa tersebut yang dihitung menggunakan harga yang berlaku pada satu tahun tertentu sebagai tahun dasar.

PDRB atas dasar harga konstan digunakan untuk mengetahui kemampuan sumber daya dalam mendorong pertumbuhan ekonomi secara riil dari tahun ke tahun atau pertumbuhan ekonomi yang tidak dipengaruhi oleh faktor harga.

\subsection{Pembiayaan}

\subsubsection{Pengertian Pembiayaan}

Pembiayaan Menurut Undang-Undang Bank Indonesia Nomor 21 Tahun 2008 tentang perbankan syariah, pembiayaan adalah penyediaan dana atau tagihan yang dipersamakan dengan itu berupa:

a. Transaksi bagi hasil dalam bentuk mudharabah dan musyarakah,

b. Transaksi sewa menyewa dalam bentuk ijarah atau sewa beli dalam bentuk ijarah muntahiyah bittamlik,

c. Transaksi jual beli dalam bentuk piutang murabahah, salam, dan istishna',

d. Transaksi pinjam meminjam dalam bentuk piutang qardh,

e. Transaksi sewa menyewa jasa dalam bentuk ijarah untuk transaksi multijasa,

berdasarkan persetujuan atau kesepakatan antara Bank Syariah (BS) dan atau Unit Usaha Syariah (UUS) dan pihak lain yang mewajibkan pihak yang dibiayai dan atau diberi fasilitas dana untuk mengembalikan dana tersebut setelah jangka waktu tertentu dengan imbalan ujrah, tanpa imbalan, atau bagi hasil bathil.

\subsubsection{Tujuan dan Fungsi Pembiayaan}

\section{Tujuan Pembiayaan Bank Syariah}

Tujuan pembiayaan bank syariah secara makro adalah sebagai berikut: (Andrianto, 2019)

- Peningkatan ekonomi umat

- Tersedianya dana bagi peningkatan usaha

- Meningkatkan produktivitas

- Membuka lapangan kerja baru

- Terjadinya distribusi pendapatan

Sedangkan tujuan pembiayaan bank syariah secara mikro adalah sebagai berikut:

- Upaya memaksimalkan laba

- Pendayagunaan sumber ekonomi

- Penyaluran kelebihan dana

- Menghindari terjadinya dana menganggur

\section{Fungsi Pembiayaan Bank Syariah}

Prinsip bank syariah dalam menjalankan pembiayaan tidak hanya sekedar mencari keuntungan dalam usaha ataupun sekedar menambah keramaian dalam bisnis perbankan di Indonesia, namun selain itu pembiayaan bank syariah memiliki fungsi lain seperti sebagai berikut: 
- Memberikan pembiayaan dengan prinsip syariah yang menerapkan sistem bagi hasil yang tidak memberatkan debitur.

- Membantu kaum dhuafa yang tidak tersentuh oleh bank konvensional karena tidak mampu memenuhi persyaratan yang ditetapkan oleh bank konvensional.

- Membantu masyarakat ekonomi lemah yang selalu dipermainkan oleh rentenir dengan membantu melalui pendanaan untuk usaha yang dilakukan.

\subsection{Perbedaan Pariwisata Konvensional, Religi dan Syariah}

Tabel 2. Perbedaan Pariwisata Konvensional, Religi dan Syariah

\begin{tabular}{|c|c|c|c|c|}
\hline No. & Item Perbandingan & Konvensional & Religi & Syariah \\
\hline 1. & Obyek & $\begin{array}{l}\text { Alam, Budaya, Heritage, } \\
\text { Kuliner }\end{array}$ & $\begin{array}{l}\text { Tempat ibadah, } \\
\text { Peninggalan Sejarah }\end{array}$ & Semuanya \\
\hline 2. & Tujuan & Menghibur & Meningkatkan & Meningkatkan Spirit \\
\hline 3. & Target & $\begin{array}{l}\text { Menyentuh kepuasaan, dan } \\
\text { kesenangan yang berdimensi } \\
\text { nafsu untuk menghibur } \\
\text { semata. }\end{array}$ & $\begin{array}{l}\text { Aspek spiritual } \\
\text { menenangkan jiwa, } \\
\text { mencari ketentraman batin } \\
\text { semata. }\end{array}$ & $\begin{array}{l}\text { Memenuhi keinginan } \\
\text { dan kesenangan serta } \\
\text { menumbuhkan } \\
\text { kesadaran beragama. }\end{array}$ \\
\hline 4. & Guide & $\begin{array}{l}\text { Memahami dan menguasai } \\
\text { informasi. Sehingga bisa } \\
\text { menarik wisatawan terhadap } \\
\text { objek wisata. }\end{array}$ & $\begin{array}{l}\text { Menguasai sejarah tokoh } \\
\text { dan lokasi yang menjadi } \\
\text { objek wisata. }\end{array}$ & $\begin{array}{l}\text { Membuat turis tertarik } \\
\text { pada obyek dan } \\
\text { membangkitkan spirit } \\
\text { religiusitas. Mampu } \\
\text { menjelaskan fungsi \& } \\
\text { peran syari'ah dalam } \\
\text { membentuk } \\
\text { kebahagiaan dan } \\
\text { kepuasan batin. }\end{array}$ \\
\hline 5. & Fasilitas Ibadah & Sekedar perlengkapan & Sekedar perlengkapan & $\begin{array}{l}\text { Menjadi bagian yang } \\
\text { menyatu }\end{array}$ \\
\hline 6. & Kuliner & Umum & Umum & Spesifik yang halal \\
\hline 7. & $\begin{array}{l}\text { Relasi Dengan } \\
\text { Masyarakat di } \\
\text { Lingkungan Obyek } \\
\text { Wisata }\end{array}$ & $\begin{array}{l}\text { Umum, komplementer dan } \\
\text { semata-mata mengejar } \\
\text { keuntungan }\end{array}$ & $\begin{array}{l}\text { Umum, komplementer } \\
\text { dan semata-mata } \\
\text { mengejar keuntungan }\end{array}$ & $\begin{array}{l}\text { Spesifik yang halal, } \\
\text { terintegrasi, interaksi, } \\
\text { berdasar prinsip-prinsip } \\
\text { syariah. }\end{array}$ \\
\hline 8. & Agenda Perjalanan & Mengabaikan waktu & Peduli waktu perjalanan & Memperhatikan waktu \\
\hline
\end{tabular}

Sumber : (Jaelani, 2017)

\subsection{Perdagangan}

Menurut (Kementrian Keuangan, 2012) Perdagangan adalah kegiatan ekonomi yang melakukan kegiatan pengumpulan dan penjualan kembali (tanpa perubahan bentuk), barang barang baru maupun bekas. Pedagang adalah perorangan atau badan usaha yang melakukan kegiatan perniagaan / perdagangan secara terus menerus dengan tujuan mencari keuntungan.

Perdagangan terbagi menjadi dua jenis yaitu :

1. Perdagangan besar

2. Perdagangan eceran (ritel)

Sementara menurut fungsi dan ruang lingkup usahanya pedagang dibedakan atas

1. Pedagang antar daerah.

2. Pedagang antar pulau.

3. Pedagang pengumpul adalah pengusaha yang berperan sebagai kolektor dan penyortir komoditi dagangannya dari para petani, produsen atau pengrajin untuk disalurkan kepada pengusaha yang lebih besar atau eksportir.

4. Pedagang kaki lima adalah perorangan yang melakukan penjualan barang - barang dengan menggunakan bangunan jalan / trotoar dan tempat - tempat untuk kepentingan umum serta tempat lain yang bukan miliknya. 


\section{Pedagang lintas batas.}

\subsection{Hotel}

Hotel adalah suatu jenis akomodasi yang mempergunakan sebagian atau seluruh bangunan untuk menyediakan jasa pelayanan penginapan, makan dan minum serta jasa lainnya bagi umum, yang dikelola secara komersial serta memenuhi ketentuan persyaratan yang ditetapkan di dalam Keputusan Pemerintah. Hotel berbintang adalah usaha yang menggunakan suatu bangunan atau sebagian bangunan yang disediakan secara khusus, dimana setiap orang dapat menginap, makan, serta memperoleh pelayanan dan fasilitas lainnya dengan pembayaran dan telah memenuhi persyaratan sebagai hotel berbintang seperti yang telah ditentukan oleh Dinas Pariwisata.

\subsection{Restoran}

Restoran adalah usaha yang menyediakan, menghidangkan dan menjual makanan/minuman bagi umum di tempat usahanya bertempat di sebagian atau seluruh bangunan permanen dilengkapi dengan peralatan dan perlengkapan proses pembuatan, penyimpanan, dan penyajian (dan telah mendapatkan surat keputusan sebagai restoran dari instansi yang membinanya).

Sementara rumah makan adalah usaha yang hanya menyediakan/menjual makanan atau hidangan dan minuman bagi umum di tempat usahanya, yang pembuatannya dari bahan baku menjadi bahan jadi bias dilakukan di tempat usahanya maupun di tempat lain, tetapi tidak mempunyai fasilitas-fasilitas lain, seperti penyimpanan, pengawetan, dan sebagainya yang memenuhi kriteria sebagai restoran.

\subsection{Hipotesis Penelitian}

Hipotesis adalah jawaban sementara terhadap rumusan masalah penelitian, dimana rumusan masalah penelitian telah dinyatakan dalam bentuk kalimat pertanyaan, dikatakan sementara karena jawaban yang diberikan hanya didasarkan pada teori relevan, belum didasarkan pada faktafakta empiris yang diperoleh melalui pengumpulan data.Adapun langkah-langkah dalam menguji hipotesis ini dimulai dengan menetapkan hipotesis nol (Ho) dan hipotesis alternative $(\mathrm{Ha})$, pemilihan tes statistik dan perhitungannya, menetapkan tingkat signifikansi, dan penetapan kriteria pengujian (Sugiyono,2017). Hipotesis yang dirumuskan dalam penelitian ini yaitu

1. Diduga adanya hubungan dan kontribusi yang menyebabkan Pembiayaan BUS dan UUS sektor perdagangan, hotel dan restoran dan PDRB sektor perdagangan, hotel dan restoran.

2. Diduga adanya pengaruh yang menyebabkan Pembiayaan BUS dan UUS sektor perdagangan, hotel dan restoran dan PDRB sektor perdagangan,hotel dan restoran.

\section{Metodologi Penelitian}

\subsection{Metode Penelitian}

Metode penelitian yang digunakan penelitian ini merupakan penelitian kuantitatif dengan jenis deskriptif asosiatif. Penelitian kuantitatif menurut (Sugiyono, 2017) merupakan suatu metode penelitian yang berlandaskan pada filsafat positivisme, digunakan untuk meneliti pada populasi atau sampel tertentu, pengumpulan data menggunakan instrumen penelitian, analisis data bersifat kuantitatif/statistik, dengan tujuan untuk menguji hipotesis yang telah ditetapkan adalah dengan metode deskriptif yang didukung oleh analisis kualitatif.

\subsection{Metode Pengumpulan Data}

1. Studi Kepustakaan

Studi Kepustakaan yaitu pengumpulan data dengan cara mempelajari buku, makalah, situs web-site, guna memperoleh informasi yang berhubungan dengan teori-teori dan konsep-konsep yang berkaitan dengan masalah dan variabel yang diteliti terdiri dari Pembiayaan BUS dan UUS 
sektor Perdagangan, Hotel dan Restoran.

2. Studi Literatur

Studi Literatur merupakan usaha pengumpulan informasi yang berhubungan dengan teoriteori dan konsep-konsep yang berkaitan dengan masalah dan variabel yang diteliti. Studi literatur tersebut didapat dari berbagai sumber yaitu:

1. Buku Referensi

2. Jurnal Pariwisata dan Keuangan Syariah

3. Media Elektronik (Internet)

4. Skripsi

\subsection{Jenis dan Sumber Data}

Jenis data yang digunakan yaitu data sekunder. Data sekunder merupakan sumber yang tidak langsung memberikan data kepada pengumpul data, misalnya lewat orang lain atau lewat dokumen (Sugiyono, 2017). Data yang diambil merupakan data triwulanan, sedangkan jenis data pada penelitian ini adalah datatime series. Penelitian menggunakan data sekunder karena peneliti mengumpulkan informasi dari data yang telah diolah oleh pihak lain. Data tersebut berupa Laporan Data Statistik Perbankan Syariah yang berasal dari website Otoritas Jasa Keuangan dan PDRB berasal dari website Badan Pusat Statistik Provinsi Aceh.

\subsection{Variabel Operasional}

Tabel 3. Variabel Operasional

\begin{tabular}{|c|c|c|c|c|c|}
\hline Nama Variabel dan Simbol & Konsep & Indikator & Sumber Data & Satuan & Skala \\
\hline $\begin{array}{c}\text { Pembiayaan pada sektor } \\
\text { Perdagangan,Hotel, dan } \\
\text { Restoran (PBPHR) }\end{array}$ & $\begin{array}{c}\text { Pembiayaan BUS } \\
\text { dan UUS yang } \\
\text { disalurkan pada } \\
\text { nasabah }\end{array}$ & $\begin{array}{c}\text { Jumlah } \\
\text { Pembiayaan }\end{array}$ & $\begin{array}{c}\text { Statistik } \\
\text { Perbankan Syariah } \\
\text { Otoritas Jasa } \\
\text { Keuangan }\end{array}$ & Rp & Rasio \\
\hline $\begin{array}{c}\text { Produk Domestik Regional } \\
\text { Bruto Sektor Perdagangan, } \\
\text { Hotel, dan Restoran }\end{array}$ & $\begin{array}{c}\text { PDRB yang } \\
\text { diperoleh } \\
\text { masyarakat }\end{array}$ & Jumlah PDRB & $\begin{array}{c}\text { Statistik Provinsi } \\
\text { Aceh }\end{array}$ & Rp & Rasio \\
\hline
\end{tabular}

Sumber: data diolah kembali

\subsection{Model Penelitian dan Teknik Analisis Data}

\subsubsection{Model Penelitian}

Model penelitian adalah model yang digunakan untuk melakukan prediksi, bagaimana perubahan nilai variabel dependen bila nilai variabel independent dinaikkan atau diturunkan nilainya. Penelitian ini menggunakan analisis regresi linear sederhana untuk menguji dan mengukur hubungan dan seberapa besar pengaruh Pembiayaan BUS dan UUS terhadap Produk Domestik Regional Bruto Sektor Perdagangan, Hotel, dan Restoran ditinjau dari Pariwisata Syariah Provinsi Aceh. Persamaan matematis analisis regresi linier sederhana dapat dirumuskan sebagai berikut:

Keterangan :

\section{PBPHR $=a+b$ INPHR}

PBPHR $=$ Variabel Dependen (Pembiayaan Perdagangan, Hotel, dan Restoran)

a $\quad=$ Konstata

$\mathrm{b} \quad=$ Koefisien regresi variabel bebas

INPHR $=$ Variabel Independen (PDRB Perdagangan, Hotel dan Restoran)

\subsubsection{Teknik Analisis Data}

Teknik analisis data yang digunakan dalam penelitian ini adalah analisis regresi linier 
sederhana dengan menggunakan bantuan Eviews 9, karena tujuan dari penelitian ini adalah untuk mengetahui pengaruh dari Pembiayaan BUS dan UUS terhadap Pendapatan Domestik Regional Bruto Sektor Perdagangan, Hotel dan Restoran.

Langkah yang dilakukan setelah pengumpulan data yaitu melakukan analisa untuk mengetahui pengaruh Pembiayaan BUS dan UUS terhadap Produk Domestik Regional Bruto Sektor Perdagangan, Hotel, dan Restoran ditinjau dari Pariwisata Syariah Provinsi Aceh. Berikut adalah tahap-tahap dalam melakukan teknik analisis data dalam penelitian ini :

\section{Uji Normalitas Data}

Sebelum melakukan uji statistik langkah awal yang harus dilakukan adalah screening terhadap data yang akan diolah. Salah satu asumsi penggunaan statistik parametrik adalah asumsi multivariate normality. Multivariate normality merupakan asumsi bahwa setiap variabel dan semua kombinasi linear dari variabel berddistribusi normal. (Ghozali,2016)

Untuk mendeteksi apakah residual berdistribusi normal atau tidak dengan membandingkan nilai Jarque-Bera (JB) dengan $\mathrm{X}^{2}$ tabel yaitu:

a. Jika probabilitas Jarque Bera $(\mathrm{JB})>0,05$ maka residualnya berdistribusi normal.

b. Jika probabilitas Jarque Bera (JB) $<0,05$ maka residualnya berdistribusi tidak normal.

\section{Korelasi dan Koefisien Determinasi}

Analisis korelasi bertujuan untuk mengukur kekuatan asosiasi (hubungan) linear antara dua variabel. Korelasi tidak menunjukkan hubungan fungsionalatau dengan kata lain analisis korelasi tidak membedakan antara variabel dependen dengan variabel independen. Berikut merupakan Tabel Interpretasi Koefisien Korelasi (Sugiyono,2014)

Tabel 4. Interpretasi Koefisien Korelasi

\begin{tabular}{|c|c|}
\hline Tingkat Hubungan & Tingkat Hubungan \\
\hline $0,00-0,199$ & Sangat Rendah \\
\hline $0,20-0,399$ & Rendah \\
\hline $0,40-0,599$ & Sedang \\
\hline $0,60-0,799$ & Kuat \\
\hline $0,80-1,000$ & Sangat Kuat \\
\hline
\end{tabular}

Koefisien determinasi $\left(\mathrm{R}^{2}\right)$ pada intinya mengukur seberapa jauh kemampuan model dalam menerangkan variasi variabel dependen. Nilai koefisien determinasi adalah antara nol dan satu. Jika $\mathrm{R}^{2}=0$, artinya variasi variabel independen tidak menjelaskan sedikitpun variasi variabel dependen. Jika $R^{2}=1$, artinya variasi variabel independen menjelaskan 100\% variasi variabel dependen.

\section{Regresi Liniear Sederhana}

Analisis regresi bertujuan menganalisis besarnya pengaruh variabel bebas (independent) terhadap variabel terikat (dependent). Regresi linier dikelompokkan menjadi 2 kelompok yaitu regresi linier sederhana dan linier berganda. Perbedaan ini berdasarkan jumlah variabel bebasnya, jika variabel bebasnya hanya 1 maka disebut linier sederhana, jika variabel bebasnya lebih dari 1 maka disebut linier berganda. Dalam analisis ini menggunakan analisis regresi linear sederhana karena menggunakan satu variabel bebas ; pembiayaan BUS dan UUS sektor perdagangan, hotel dan restoran dan satu variabel dan satu variabel terikat yaitu PDRB sektor perdagangan hotel dan restoran.

Syarat -syarat yang digunakan untuk melakukan analisis regresi linear sederhana adalah sebagai berikut : 

a. Jumlah sampel yang digunakan harus sama;
b. Jumlah variabel bebas (variabel $\mathrm{X}$ ) adalah satu;
c. Nilai residual harus berdistribusinormal;
d. Terdapat hubungan yang linier antara variabel independen dan variabel independen;
e. Tidak terjadi gejala heteroskedastistitas;
f. Tidak terjadi gejala autokorelasi (untuk data timeseries).
4. Pengujian Hipotesis

Uji Statisik $T$ pada dasarnya menunjukkan seberapa jauh pengaruh satu variabel penjelas/independen secara individual dalam menerangkan variasi variabel independen. Untuk menguji hipotesis digunakan uji statistik $\mathrm{t}$ dengan kriteria pengambil keputusan pada penelitian sebagai berikut

a. Hipotesis nol(Ho) yang hendak diuji adalah apakah suatu parameter (bi) sama dengan nol, atau :

Ho : bi $=0$

Artinya Pembiayaan BUS dan UUS tidak berpengaruh signifikan terhadap Produk Domestik Regional Bruto Sektor Perdagangan, Hotel, dan Restoran ditinjau dari Pariwisata Syariah Provinsi Aceh.

b. Hipotesis nol(Ho) yang hendak diuji adalah apakah suatu parameter (bi) sama dengan nol, atau :

Ho $:$ bi $=0$

Artinya Pembiayaan BUS dan UUS tidak berpengaruh signifikan terhadap Produk Domestik Regional Bruto Sektor Perdagangan, Hotel, dan Restoran ditinjau dari Pariwisata Syariah Provinsi Aceh.

\section{Hasil dan Pembahasan}

\subsection{Gambaran Objek Penelitian}

Provinsi Aceh adalah salah satu provinsi di Indonesia dengan letak yang strategis di kawasan Selat Malaka. Provinsi ini merupakan jalur pelayaran internasional serta didukung dengan kekayaan alam, pesona budaya daerah, keunikan sejarah dan peninggalan Tsunami "Tsunami Heritage". Sehingga dengan melakukan berbagai upaya pengembangan dan promosi pariwisata daerah sebagai salah satu Daerah Tujuan Wisata (DTW) unggulan yang nyaman bagi daya tarik minat wisatawan.

Pada 26 Desember 2004 Provinsi Aceh telah terjadi bencana Tsunami yang menimbulkan banyak korban jiwa dan menyebabkan kerusakan terhadap bangunan dan fasilitas umum yang ada di wilayah tersebut. Sehingga banyak hikmah untuk memperbaiki kembali seluruh tatanan wilayah yang bisa dikembangkan menjadi sektor pariwisata terkenal di nusantara dan mancanegara.

Aceh juga memiliki wisata dataran tinggi yang mampu menarik wisatawan yaitu Dataran Tinggi Gayo. Dataran Tinggi Gayo menyuguhkan keindahan alam yangg didukung dengan letak geografis yang menjanjikan dan keindahan alam dengan kesejajaran perbukitan yang mempesona. Selain tiu Dataran Tinggi Gayi juga menyuguhkan cita rasa Gayo yaitu Kopu Arabika Gayo yang sudah terkenal di seluruh dunia. Tanaman kopi yang tumbuh di dataran tinggi menjadikan Kopi Arabika Gayo memiliki cita rasa yang khas (Fadhilah et al., 2020).

Semenjak dipromosikan oleh Pemerintah Budaya dan Pemerintah Pariwisata Provinsi Aceh kembali memenangkan tiga kategori pada Komperisi Pariwisata Halal Nasional 2016 versi Kementerian Pariwisata Republik Indonesia. Adapun kategori tersebut yaitu Destinasi Budaya Ramah Wisatawan Muslim Terbaik, Airport Ramah Wisatawan Muslin terbaik (Bandara Sultan 
Iskandar Muda) dan Daya Tarik Wisara Terbaik (Masjid Raya Baiturrahman Banda Aceh). Ini merupakan salah satu dari daya tarik wisatawan domestik maupun mancanegara untuk bisa merasakan langsung pariwisata syariah yang ada di Provinsi Aceh untuk dikunjungi.

Terdapat peranan penting BUS dan UUS pada sektor pariwisata syariah untuk memberikan kemudahan dalam menyalurkan pembiayaan dan penghimpun dana bagi masyarakat membuka lapangan usaha di sektor pariwisata. Penyaluran dana pembiayaan tersebut dimanfaatkan masyarakat untuk mengembangkan usaha sektor pariwisata agar meningkatkan pendapatannya. Penelitian ini menggunakan data sekunder Pembiayaan Bank Umum Syariah, Usaha Unit Syariah Sektor Perdagangan, Hotel, dan Restoran yang berada di Provinsi Aceh Periode 2010-2018. Data yang digunakan diperoleh dari Statistik Perbankan Syariah yang dipublikasikan oleh Otoritas Jasa Keuangan.

\subsection{Analisis Data}

1. Uji Normalitas Data

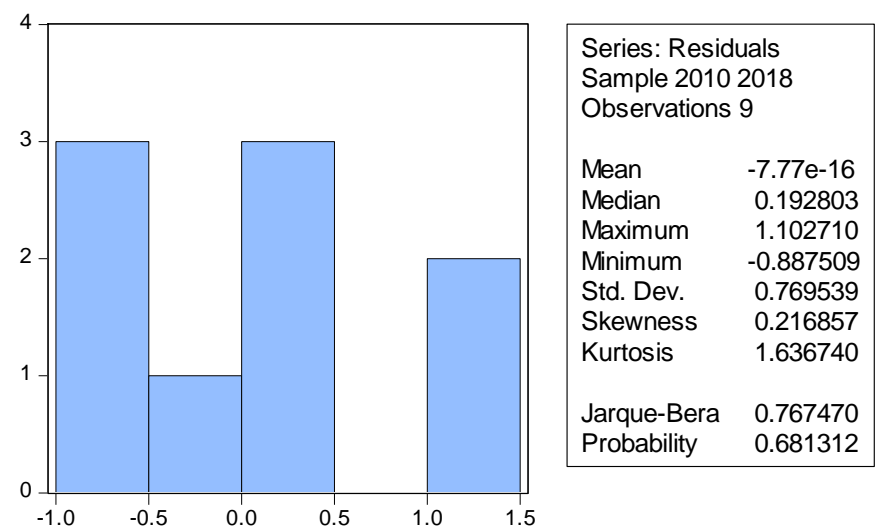

Gambar 2. Uji Normalitas Data

Berdasarkan gambar Histogram Normality diatas dapat dilihat nilai probability sebesar 0.681312. Ini berarti nilai probability lebih besar dari 0.05. Dapat disimpulkan bahwa H0 diterima dengan probability sebesar 0.681312 dan data yang digunakan dalam penelitian ini berdistribusi normal sehingga baik untuk digunakan.

2. Korelasi dan Koefisien Determinasi

Tabel 5. Korelasi dan Koefisien Determinasi

\begin{tabular}{|l|l|l|l|}
\hline \multicolumn{2}{|c|}{$R$} & \multicolumn{2}{c|}{0.938574} \\
\hline R-squared & 0.880921 & Mean dependent var & 1.814 .778 \\
\hline Adjusted R-Squared & 0.863910 & S.D. dependent var & 2.230 .044 \\
\hline
\end{tabular}

Berdasarkan tabel 5 diatas, hubungan antara pembiayaan BUS dan UUS dengan Pendapatan Domestik Regional Bruto sektor Perdagangan, Hotel dan Restoran terdapat korelasi yang sangat kuat ini ditunjukan dari nilai R sebesar 0.938574.

Variabel Pendapatan Domestik Regional Bruto Sektor Perdagangan, Hotel, dan Restoran dapat mempengaruhi variabel Pembiayaan sektor Perdagangan, Hotel, dan Restoran dengan nilai $\mathrm{R}^{2}$ sebesar 88,0921 \%, sedangkan sisanya 11,9079\% dipengaruhi oleh variabel lain diluar penelitian. 
3. Regresi Linear Sederhana

Tabel 6. Regresi Linear Sederhana

\begin{tabular}{|ccccc|}
\hline Dependent Variable: PBPHR & & & \\
Method: Least Squares & & & \\
Date: 08/05/20 Time: 08:16 & & & \\
Sample: 20102018 \\
Included observations: 9 & & & & \\
\hline \hline Variable & Coefficient & Std. Error & t-Statistic & Prob. \\
\hline \hline C & 13.23102 & 0.736224 & 17.97146 & 0.0000 \\
INPHR & 1.060661 & 0.147393 & 7.196154 & 0.0002 \\
\hline \hline
\end{tabular}

Sumber : Data diolah kembali

Berdasarkan hasil output regresi pada tabel, maka didapatkan hasil persamaan regresi linear sederhana :

\section{PBPHR $=13,23102+1,060661$ INPHR}

Dimana:

PBPHR = Pembiayaan Sektor Perdagangan, Hotel, dan Restoran

INPHR = Pendapatan Domestik Regional Bruto Sektor Perdagangan, Hotel dan Restoran.

Berdasarkan hasil tersebut, menggunakan nilai koefisien regresi untuk setiap variabel dalam penelitian yang dijelaskan dalam model berdasarkan alat analisis data diatas, diperoleh hasil:

1. Nilai konstanta yang didapat sebesar 13.23102. Artinya jika Produk Domestik Regional Sektor Perdagangan, Hotel dan Restoran nilainya 0, maka Pembiayaan Sektor Perdagangan, Hotel, dan Restoran nilainya 13,23102.

2. Nilai variabel INPHR 1.060661 artinya dengan asumsi PDRB sektor Perdagangan, Hotel dan Restoran dapat meningkatkan PDRB sektor Perdagangan, Hotel, dan Restoran sebesar $1.060661 \%$.

\subsection{Pengujian Hipotesis}

Uji hipotesis dimaksudkan untuk mengetahui hubungan-hubungan antara variabel terikat dengan variabel bebas. Uji hipotesis secara statistik dilakukan dengan menggunakan uji parsial (uji t). Adapun hasil uji t adalah sebagai berikut:

Tabel 7. Hasil Uji t (Parsial)

\begin{tabular}{|ccccc|}
\hline \hline Variable & Coefficient & Std. Error & t-Statistic & Prob. \\
\hline \hline C & 13.23102 & 0.736224 & 17.97146 & 0.0000 \\
INPHR & 1.060661 & 0.147393 & 7.196154 & 0.0002 \\
\hline \hline
\end{tabular}

Sumber : Data diolah kembali

Hipotesis Pengarus PBPHR (Pembiayaan Sektor Perdagangan, Hotel dan Restoran) terhadap INPHR (Pendapatan Sektor Perdagangan, Hotel, dan Restoran)

$\mathrm{H}_{0}:$ p-value $>0,05$ INPHR tidak berpengaruh signifikan terhadap PBPHR

$\mathrm{H}_{\mathrm{a}}:$ p-value $<0,05$ INPHR berpengaruh signifikan terhadap PBPHR

Hasil koefisien regresi untuk variabel tersebut menunjukanbahwa nilai probability sebesar $0,0002<0,05$, maka $\mathrm{H}_{0}$ ditolak dan $\mathrm{Ha}$ diterima, sehingga dapat disimpulkan bahwa terdapat pengaruh yang signifikan antara INPHR terhadap PBPHR.

\subsection{Pembahasan}

Berdasarkan analisis data diatas, pembiayaan BUS dan UUS memiliki hubungan yang sangat kuat dengan Produk Domestik Regional Bruto sektor Perdagangan, Hotel, dan Restoran. 
Kontribusi yang terjalin sangat besar diantara pembiayaan dan PDRB sektor tersebut.

Produk Domestik Regional Bruto Sektor Perdagangan, Hotel, dan Restoran memiliki pengaruh positif dan signifikan terhadap pembiayaan sektor Perdagangan, Hotel, dan Restoran Provinsi Aceh. Hasil ini didukung dengan penelitian (Gunawan \& Parikesit, 2017) yang menunjukkan perdagangan, hotel, dan restoran yang pengaruh positif dan signifikan terhadap Produk Domestik Regional Bruto.

Pada hasil penelitian diatas berbanding terbalik dengan penelitian Gery S, Dominicu S dan Laily (2014) menunjukkan hubungan negatif antara rasio pembiayaan sektor perdagangan, hotel dan restoran dan Non Performing Financing terjadi karena semakin tinggi pembiayaan bermasalah dari sektor perdagangan, hotel, dan restoran maka akan menyebabkan dana perbankan syariah menjadi tidak berputar dari satu nasabah ke nasabah lain, karena terjadi kemacetan pada pembiayaan tersebut. Penelitian lain juga menunjukkan bahwa ketatnya pengendalian Non Performing Financing Murabahah yang dilakukan oleh manajemen bank dengan melakukan seleksi ketat terhadap setiap pengajuan (Anisa \& Tripuspitorini, 2013).

Faktor pendukung lain dalam pertumbuhan PDRB sektor ini adalah adanya investasi. Hal ini sesuai dengan teori pertumbuhan Harrod-Domar yang mengatakan bahwa investasi mempunyai pengaruh yang signifikan terhadap pertumbuhan sektor perdagangan. Ini berarti pertumbuhan sektor perdagangan, hotel, dan restoran akan berpengaruh secara signifikan terhadap pertumbuhan PDRB Provinsi Aceh, Apabila investasi pada sektor tersebut dapat dimanfaatkan secara optimal. Dengan hal ini memberikan kontribusi yang besar pada Produk Domestik Regional Bruto Provinsi Aceh.

\section{Penutup}

Berdasarkan hasil penelitian tentang pengaruh pembiayaan BUS dan UUS terhadap produk domestik regional bruto sektor perdagangan, hotel, dan restoran ditinjau dari pariwisata syariah Provinsi Aceh, maka dapat diambil beberapa kesimpulan :

a) Pembiayaan BUS dan UUS sektor Perdagangan, Hotel, dan Restoran Provinsi Aceh memiliki hubungan yang sangat kuat dan berkontribusi sangat kuat terhadap Pendapatan Domestik Regional Bruto sektor Perdagangan, Hotel, dan Restoran.

b) Pembiayaan BUS dan UUS sektor Perdagangan, Hotel, dan Restoran Provinsi Aceh berpengaruh positif signifikan terhadap Pendapatan Domestik Regional Bruto Sektor Perdagangan, Hotel, dan Restoran.

Setelah melakukan analisis pengaruh pembiayaan BUS dan UUS terhadap Produk Domestik Regional Bruto Sektor Perdagangan, Hotel, dan Restoran ditinjau dari pariwisata syariah Provinsi Aceh, maka terdapat hal yang perlu diperhatikan bagi peneliti selanjutnya :

a) Dapat menggunakan penelitian kali ini dan dapat dikembangakan lebih luas.

b) Diharapkan untuk menambah objek penelitian seperti wilayah lain yang sedang mengembangkan pariwisata syariah.

\section{Daftar Pustaka}

Aliah. (2016). Role of the Tourism Sector in Economic Development in Indonesia: Social Accounting Matrix (SAM) Approach.

Amnar, S., Muhammad, S., \& Syechalad, M. N. (2017). Pengaruh Pariwisata Terhadap Pertumbuhan Ekonomi Di Kota Sabang. Jurnal Ekonomi Dan Kebijakan Publik Indonesia, 4(1), $13-22$.

Andrianto, \& Firmansyah, A. M. (2019). Manajemen Bank Syariah (Implementansi Teori dan Praktek) 
(M. Qiara (Ed.)).

Anisa, L. S., \& Tripuspitorini, F. A. (2013). Analisis Pengaruh Dana Pibak Ketiga, Non Performing Finance Murabahah dan Inflasi Terhadap Pembiayaan Murabahah Pada Bank Umum Syariah di Indonesia. 52 64.

Apriyanthi, R., Purbayati, R., \& Setiawan. (2019). Faktor-Faktor Yang Mempengaruhi Pembiayaan Sektor Konstruksi Pada Perbankan Syariah di Indonesia. Jurnal Ekonomi Dan Perbankan, 4(1), 15-26.

BPS ACEH. (2019). https:/aceh.bps.go.id

Djakfar Muhammad. (2017). Halal Tourism: Multidimension Perspective. UIN MALIKI.

El-Gohary, H. (2016). Halal tourism, is it really Halal? Tourism Management Perspectives, 19, 124-130. https://doi.org/10.1016/j.tmp.2015.12.013

Fadhilah, F. G., Widyastuti, I. P., \& Rizqullah, M. F. S. (2020). Wisata Halal Aceh Sebagai Instrumen Peningkatan Perekonomian Indonesia Dalam Menggandeng Wisatawan Mancanegara. 3(1), 48-58.

Fahreza, A., \& Masbar, R. (2018). Pengaruh jumlah wisatawan terhadap PDRB kabupaten Aceh Singkil melalui pajak daerah dan retribusi daerah. 3(2), 204-213.

Gunawan, \& Parikesit, P. (2017). Analisis Pengarub Sektor Perdagangan, Hotel dan Restoran Terhadap Pertumbuban Ekonomi (Studi Kasus pad Kota Surabaya). 15(5), 55-68.

Halal Media Japan. (2016). https://www.halalmedia.jp/archives/19962/japan-won-in-world-halaltourism-awards-2016/2/.

Jaelani, A. (2017). International Review of Management and Marketing Halal Tourism Industry in Indonesia: Potential and Prospects. International Review of Management and Marketing, 7(3), 2534. http:www.econjournals.com

Japan Halal Association. (2012). padaihttps://www.jhalal.com/english.

Kementrian Keuangan. (2012). Laporan Tim Kajian Profil Sektor Riil : Sektor Perdagangan, Hotel, dan Restoran. Kementrian Keuangan Republik. Indonesia Badan Kebijakan Fiskal Pusat Kebijakan Ekonomi Makro.

Saleh, R., \& Anisah, N. (2018). Pariwisata Halal Di Aceh: Gagasan Dan Realitas Di Lapangan. Sahafa Journal of Islamic Communication, 1(2), 79-92. https://doi.org/10.21111/sjic.v1i2.2849

Setiawan, I. (2019). The Role of Islamic Banking in the Development of Economic Sectors in Indonesia. International Journal of Applied Business Research, 1(02), 88-99. https://doi.org/10.35313/ijabr.v1i02.70

SPS OJK 2010-2018. (2019). https://www.ojk.go.id/id/kanal/syariah/data-dan-statistik/statistikperbankan- syariah/default.aspx

Sugiyono. (2017). Metode Penelitian Pendidikan (Pendekatan Kuantitatif, Kualitatif dan R $\odot D)$. Alfabeta.

Suryadi, G., Priyarsono, D. S., \& Arsyianti, L. D. (2014). Analisis Pembiayaan Sektor Perdagangan Hotel dan Restoran pada Perbankan Syariah di Indonesia. Al-Muzara'ah, 2(2), 150-178. https://doi.org/10.29244/jam.2.2.150-178

Yusof, S. M., \& Shutto, N. (2014). The Development of Halal Food Market in Japan: An Exploratory Study. Procedia - Social and Behavioral Sciences, 121 (September 2012), 253-261. https://doi.org/10.1016/j.sbspro.2014.01.1126 